\title{
\begin{tabular}{l|l|l} 
Jurnal Kependidikan Dasar & $\begin{array}{l}\text { Volume : } \\
\text { Nomor }\end{array} 11$ \\
& Tahun $: 2019$ \\
\hline Islam Berbasis Sains
\end{tabular}
}

\section{Pengelolaan Kelas dalam Melaksanakan Pembelajaran Aktif}

\author{
Siti Muyasaroh \\ sitimuyasaroh@gmail.com
}

\begin{abstract}
Class management is a planned activity that is deliberately carried out by the teacher with the aim of creating and maintaining optimal conditions, building a positive socio-emotional climate and creating a good atmosphere of interpersonal relations. So that it is expected that the learning and teaching process can run effectively and efficiently, so that learning objectives are achieved. Improving the quality of education will be achieved if the teaching and learning process held in the classroom is truly effective and is useful for achieving the ability of the knowledge, attitudes and skills expected. Because basically the teaching and learning process is at the core of the overall education process, including the teacher is one of the important factors in determining the success of the teaching and learning process in the classroom.
\end{abstract}

Keyword: Class Management, Active Learning

\begin{abstract}
Abstrak
Pengelolaan kelas adalah kegiatan yang terencana yang sengaja dilakukan oleh guru dengan tujuan untuk menciptakan dan mempertahankan kondisi yang optimal, membangun iklim sosio-emosional yang positif serta menciptakan suasana hubungan interpersonal yang baik. Sehingga diharapkan proses belajar dan mengajar dapat berjalan secara efektif dan efesien, sehingga tercapai tujuan pembelajaran. Peningkatan mutu pendidikan akan tercapai apabila proses belajar mengajar yang diselenggarakan di kelas benar-benar efektif dan berguna untuk mencapai kemampuan pengetahuan, sikap dan keterampilan yang diharapkan. Karena pada dasarnya proses belajar mengajar merupakan inti dari proses pendidikan secara keseluruhan, di antaranya guru merupakan salah satu faktor yang penting dalam menentukan berhasilnya proses belajar mengajar di dalam kelas.
\end{abstract}

\section{Kata Kunci: Pengelolaan Kelas, Pembelajaran Aktif}

\section{Pendahuluan}

Keberhasilan pembelajaran dalam kelas salah satu fakrornya adalah pengelolaan kelas. Guru yang kreatif pada umumnya mempunyai berbagai strategi pengelolaan kelas yang baik dan dapat diimplementasikan sesuai situasi dan kondisi. Guru memiliki andil yang sangat besar terhadap keberhasilan pembelajaran di sekolah. Di dalam kelas 
guru melaksanakan dua kegiatan pokok yaitu kegiatan belajar mengajar dan pengelolaan kelas. Kegiatan mengajar pada hakikatnya adalah proses mengatur dan mengorganisasi lingkungan yang ada di sekitar siswa. Semua komponen pengajaran yang meliputi tujuan, bahan pelajaran, kegiatan belajar mengajar, metode, alat dan sumber, serta evaluasi diperankan secara optimal guna mencapai tujuan pengajaran yang telah ditetapkan sebelum pengajaran dilaksanakan.

Pengelolaan kelas tidak hanya berupa pengaturan kelas, fasilitas fisik dan rutinitas, melainkan juga mengelola berbagai hal yang tercakup dalam kompnen pembelajaran. Kegiatan pengelolaan kelas dimaksudkan untuk menciptakan dan mempertahankan suasana dan kondisi kelas yang kondusif. Sehingga proses belajar mengajar dapat berlangsung secara efektif dan efesien. Kedua tujuan ini harus dicapai dalam kelas, karena di kelaslah segala aspek pembelajaran bertemu dan berproses, Guru mengajar dengan segala kemampuannya, murid dengan segala latar belakang dan sifat-sifat individualnya, Kurikulum dengan segala komponennya, dan materi serta sumber pelajaran dengan segala pokok bahasanya bertemu dan bepadu serta berinteraksi di kelas. Bahkan hasil dari pendidikan secara keseluruhan sangat ditentukan oleh apa yang terjadi di kelas. Oleh sebab itu sudah selakyaknya kelas dikelola dengan baik, profesional, dan harus terus-menerus dalam perbaikan (continoues improvment).

\section{Konsep Dasar dan Tujuan Pengelolaan Kelas \\ Pengertian Pengelolaan Kelas}

Pengelolaan kelas adalah suatu usaha yang dilakukan oleh penanggung jawab kegiatan belajar mengajar atau yang membantu dengan maksud agar dicapai kondisi optimal sehingga dapat terlaksana kegiatan belajar seperti yang diharapkan. ${ }^{1}$ Pengelolaan kelasadalah kegiatan mengatur tata ruang kelas untuk pengajaran dan menciptakan iklim belajar mengajar yang serasi. ${ }^{2}$ Pengelolaan kelas adalah usaha dari pihak guru untuk menata kehidupan kelas yang dimulai dari perencanaan kurikulumnya, penataan prosedur dan sumber belajarnya, lingkungannya untuk memaksimalkan efesiensi, memantau kemajuan siswa dan mengantisipasi masalah-masalah yang mungkin timbul. ${ }^{3}$

Definisi di atas dapat disimpulkan bahwa pengelolaan kelas adalah kegiatan yang terencana yang sengaja dilakukan oleh guru dengan tujuan untuk menciptakan dan mempertahankan kondisi yang optimal, membangun iklim sosioemosional yang positif serta menciptakan suasana hubungan interpersonal yang baik. Sehingga diharapkan proses belajar dan mengajar dapat berjalan secara efektif dan efesien, sehingga tercapai tujuan pembelajaran.

Dari sini dipahami bahwa pengelolaan kelas terdapat dua segi, yaitu; pengelolaan yang menyangkut siswa, dan pengelolaan fisik (ruangan, perabot, alat pelajaran).

Pengelolaan kelas sendiri berbeda dengan pengelolaan pembelajaran. Pengelolaan pembelajaran lebih menekankan pada kegiatan perencanaan, pelaksanaan, evaluasi dan tindak lanjut dalam suatu pembelajaran. Sedangkan pengelolaan kelas lebih berkaitan dengan upaya-upaya

\footnotetext{
1 Suharsimi Arikunto, Pengelolaan Kelas dan Siswa (Jakarta: Bumi Aksara, 2001), 68.

2 Komar E dan Uus Rusnadi, Pengelolaan Belajar dan Kelas (Jakarta: PT Setia Mulya, 1993), 7.

3 Cece Wijaya dan A. Tabrani Rusyan, Kemampuan Dasar Guru dalam Proses Belajar Mengajar (Bandung: Rosda Karya, 1992), 113.
} 
untuk menciptakan dan mempertahankan kondisi yang optimal unntuk terjadinya proses belajar ( pembinaan rapport, penghentian perilaku peserta didik yang menyelewengkan perhatian kelas, pemberian ganjaran, penyelesaian tugas oleh peserta didik secara tepat waktu, penetapan norma kelompok yang produktif), didalamnya mencakup pengaturan orang (peserta didik) dan fasilitas.

Adapun pengelolaan kelas menurut permendikbud nomer 22 tahun 2016 tentang standart proses pendidikan dasar dan menengah bab IV tentang pelaksanaan pembelajaran item 4; sebagaimana berikut

1. Guru wajib menjadi teladan yang baik bagi peserta didik dalam menghayati dan mengamalkan ajaran agama yang dianutnya serta mewujudkan kerukunan dalam kehidupan bersama.

2. Guru wajib menjadi teladan bagi peserta didik dalam menghayati dan mengamalkan perilaku jujur, disiplin, tanggung jawab, peduli (gotong royong, kerja sama, toleran, damai), santun, responsif dan proaktif dan menunjukkan sikap sebagai bagian dari solusi atas berbagai permasalahan dalam berinteraksi secara efektif dengan lingkungan sosial dan alam serta dalam menempatkan diri sebagai cerminan bangsa dalam pergaulan dunia.

3. Guru menyesuaikan pengaturan tempat duduk peserta didik dan sumber daya lain sesuai dengan tujuan dan karakteristik proses pembelajaran.

4. Volume dan intonasi suara guru dalam proses pembelajaran harus dapat didengar dengan baik oleh peserta didik.
5. Guru wajib menggunakan kata-kata santun, lugas dan mudah dimengerti oleh peserta didik.

6. Guru menyesuaikan materi pelajaran dengan kecepatan dan kemampuan belajar peserta didik.

7. Guru menciptakan ketertiban, kedisiplinan, kenyamanan, dan keselamatan dalam menyelenggarakan proses pembelajaran.

8. Guru memberikan penguatan dan umpan balik terhadap respons dan hasil belajar peserta didik selama proses pembelajaran berlangsung.

9. Guru mendorong dan menghargai peserta didik untuk bertanya dan mengemukakan pendapat.

10.Guru berpakaian sopan, bersih, dan rapi. 11.Pada tiap awal semester, guru menjelaskan kepada peserta didik silabus mata pelajaran; dan

12.Guru memulai dan mengakhiri proses pembelajaran sesuai dengan waktu yang dijadwalkan. ${ }^{4}$

\section{Sasaran pengelolaan kelas}

Adapun sasaran yang dikelola dalam pengelolaan kelas itu meliputi manusia dan nonmanusia. Manusia yang dimaksud yaitu siswa, sedangkan nonmanusia yaitu tempat berlangsungnya belajar mengajar. Sasaran yang pertama yaitu manusia/peserta didik dalam kelas, sehingga akan mempunyai fungsi sebagai berikut;

1. Mendorong siswa mengembangkan tanggung jawab individu terhadap tingkah lakunya,

2. Membantu siswa unutk mengerti tingkah laku yang sesuai dengan tata tertib kelas, dan memahami bahwa teguran guru

4 Peraturan Menteri Pendidikan dan Kebudayaan, "Nomor 22 Tahun 2016 Tentang Standar Proses Pendidikan Dasar Dan Menengah," Jakarta: Kementerian Pendidikan dan Kebudayaan, 2016. 
merupakan suatu peringatan dan bukan kemarahan, dan

3. Menimbulkan rasakewajiban melibatkan diri dalam tugas- tugas serta bertingkah laku yang sesuai dengan aktivitas kelas.

Adapun sasaran yang kedua yaitu mengenai tempat berlangsungnya proses belajar mengajar, adalah sebagai berikut:

1. Lingkungan fisik kelas

Lingkungan fisik kelas sangat besar pengaruhnya terhadap keberhasilan pengajaran. Kelas yang tidak teratur, meja berserakan, kotor, dan sebagainya akan mengganggu kelancaran proses interaksi antar guru dengan siswa.

Ada beberapa langkah praktis yang perlu diperhatikan dalam menciptakan lingkungan fisik kelas yang sehat antara lain :

a. lingkungan fisik kelas harus bersih dan sehat,

b. kelas merupakan suatu tempat yang indah dan menyenangkan Usaha seperti ini dapat dilakukan dengan memasang berbagai dekorasi, dan gambar-gambar edukatif, sehingga benda-benda yang ada di dalam kelas itu dapat menjadi butir fokal kegiatan belajar, dan

c. lingkungan fisik kelas harus mengandung unsur kesehatan, peredaran udara yang teratur, dan cahaya yang memadai sehingga tidak menyilaukan mata.

2. Pengaturan Tempat duduk Anak

Pengaturan tempat duduk anak dalam kelas biasanya berderet menghadap papan tulis dan guru. Dalam hal ini, ada beberapa hal yang perlu diperhatikan mengenai tempat duduk anak, antara lain: a. Usahakan sebelum pelajaran dimulai, tempat duduk paling depan terisi penuh,

b. Anak-anak yang berpostur tubuh tinggi sebaiknya duduk pada bagian belakang sedangkan yang pendek di depan, sehingga papan tulis akan tampak jelas oleh semua pihak, dan

c. jika terdapat beberapa anak yang berbuat gaduh, anak tersebut dipindahkan tempat duduknya pada deretan bagian depan tanpa menghiraukan pendek/tingginya. ${ }^{5}$

Dari uraian tersebut di atas, jelaslah bahwa prestasi belajar atau sukses dan tidaknya pengajaran sangat ditentukan juga oleh pengelolaan kelas yang efektif. Atau, untuk menciptakan suasa yang dapat menumbuhkan gairah belajar, meningkatkan prestasi belajar siswa, dan lebih memungkinkan guru memberikan bimbingan dan bantuan terhadap siswa dalam belajar, diperlukan pengorganisasian kelas yang memadai.

Keberhasilan pengajaran dalam arti tercapainya tujuan tujuan instruksional sangat tergantung pada kemampuan mengatur kelas. Kelas yang baik dapat menciptakan situasi yang memungkinkan anak belajar sehingga merupakan titik awal keberhasilan pengajaran. Akhirnya dapat ditegaskan bahwa kondisi yang menguntungkan dalam kelas merupakan prasyarat bagi terjadinya proses belajar mengajar yang efektif.

5 Sunhaji, Strategi Pembelajaran, Konsep Dasar, Metode, dan Aplikasi dalam Proses Belajar Mengajar, vol. 3 (Yogyakarta: Grafindo Litera Media, 2009), 95-96. 


\section{Pendekatan-pendekatan dalam Pengelolaan Kelas}

Sunhaji dalam bukunya mengemukakan ada tiga pendekatan yang dipakai dalam mengelola kelas yaitu:

1. Pendekatan modifikasi prilaku,

2. pendekatan iklim sosial emosional, dan

3. Pendekatan proses kelompok.

Ketigapendekatantersebutdi dalamnya terdapat teknik- teknik yang dinilai mamadai dari berbagai pertimbangan untuk digunakan dalam mengelola kelas.

\section{Pendekatan modifikasi perilaku}

Pendekatan ini berdasar pada psikologi behavioral dengan anggapan dasar bahwa tingkah laku manusia yangbaik maupun yang buruk dalam batas-batas tertentu $\mathrm{m}$ hasil belajar.

Dalam pendekatan ini, terdapat empat teknik yang dapat digunakan untuk membentuk tingkah laku manusia sesuai denganyangdikehendaki,mempertahankan atau meningkatkan tingkah laku manusia yang dikehendaki serta mengurangi atau menghilangkan tingkah laku manusia yang tidak dikehendaki. Tehnik tersebut yaitu:

a. Penguatan positif (positif reinforcement) Adapun cara penggunaan pemberian penguatan ini adalah:

1) penguatan pribadi, misalnya ditunjukan kepada siswa tertentu dengan menyebutkan namanya sambil memandang kepada siswa yang berkepentingan langsung, seperti dengan kata-kata "tepat jawabanmu" atau "bagus"

2) penguatan kelompok siswa. Penguatan ini diberikan kepada kelompok siswa, umpamanya apabila satu kelas telah menyelesaikan tugas dengan baik atau hasil ujian sisipan baik, katakan pada kelas dengan kalimat "Bapak bangga dengan kelas ini mudah-mudahan dapat dipertahankan prestasinya terus, dan selanjutnya

3) teknik penguatan perlu adanya variasi dalam penggunaannya. Misalnya, jikalau tiap kali guru memberi penguatan dengan kalimat verbal seperti "bagus, pintar, dan lainlain, maka hal tersebut nantinya akan membosankan, oleh karena itu harus bervariasi dengan cara lain, misalnya dengan mengacungkan ibu jari saja pada kelas.

b. Penguatan negatif (negative reinformement)

Penguatan negatif yaitu pengurangan hingga penghilangan stimulus yang tidak menyenangkan untuk mendorong terulang kembali suatu tingkah laku yang timbul sebagai akibat dari pengurangan/penghilangan tersebut. Misalnya guru ingin agar siswa berani mengeluarkan pendapat (stimulus yang tidak menyenangkan) bila siswa mulai berani mengeluarkan pendapat suatu saat tanpa menunggu ditunjuk oleh guru, maka guru mulai mengurangi secara berangsur-angsur cara menunju langsung tersebut (penguatan negatif).

c. Penghapusan (extinction).

Penghapusan yang dimaksud di sini adalah sebagai usaha mengubah tingkah laku siswa dengan cara menghentikan pemberian respon terhadap suatu tingkahlakusiswayangsemula dikuatkan dengan respon-respon tersebut. Misalnya, siswa selalu mengomentari penjelasan guru saat guru sedang menerangkan Untuk menghilangkan kebiasaan tersebut, teknik yang dapat digunakan adalah penghapusan yaitu 
dengan menghentikan pemberian respon yang memberikan kesan kepada siswa bahwa guru tidak keberatan terhadap kebiasaan tersebut (padahal guru sebenarnya tidak mengharapkan komentar tersebut)

d. Hukuman

Sebenarnya, penguatan negatif dan penghapusan tersebut sudah tergolong hukuman, namun secara tidak langsung. Hukuman dalam pengelolaan kelas dilaksanakan manakala siswa sudah tidak bisa ditenangkan kembali lewat berbagai teknik tersebut. ${ }^{6}$

\section{Pendekatan iklim sosial emosional}

Pendekatan ini bertolak dari anggapan dasar bahwa kegiatan belajar mengajar yang efektif dan efisien memersyaratkan hubungan sosial emosional yang baik antara guru dan siswa dan antara siswa dengan sesama siswa. Seperti pengalaman dalam kehidupan sehari-hari menunjukan kepada kita bahwa bila kita dengan patner bisa baik dalam kerjasama dan dapat berlangsung dengan lancar, maka jika terdapat kesalahpahaman dapat dengan mudah dicari jalan keluarnya. Demikian juga dengan kegiatan belajar mengajar di kelas. Untuk menciptakan hubungan yang baik antara guru dengan siswa diperlukan sikap-sikap tertentu seperti terbuka sikap menerima dan menghargai siswa sebagai manusai, sikap demokratis dan sebaginya sehingga kelas akan tenang dan menerima penjelasan guru.

\section{Pendekatan proses kelompok}

Pendekatan ini bertolak dari anggapan dasar bahwa kegiatan belajar mengajar yang efektif berlangsung dalam konteks kelompok, yaitu kelompok kelas. Peranan

6 Sunhaji, 3:97. guru dalam rangka pengelolaan kelas adalah menciptakan kelompok kelas yang mempunyai ikatan yang kuat serta dapat bekerja secara efektif dan efisien. Untuk memperkuat ikatan kelompok tersebut, maka diperlukan adanya satu tujuan, aturan, dan pimpinan. Guru harus mengarahkan siswa pada tujuan kelas yakni tujuan pembelajaran, karena itu tujuan pembelajaran harus dijelaskan dulu secara realistis serta mengomunikasikanya secara jelas kepada siswa. Aturan yang dimaksud adalah aturan yang dibuat bersama antara guru dengan siswa atau disetujui oleh siswa untuk mengikat disebut yang padu. Dalam istilah ajaran, sering dengan kontrak belajar. Adapun pimpinan guru yang menjadi pimpinan kelompok siswa di kelas tempat ia mengajar. Seorang pemimpin harus menjelaskan tujuan lebih dulu pada kelompoknya dan membentuk aturan yang ketat, seperti siswa dilarang masuk setelah 25 menit pelajaran dimulai dan sebagainya. ${ }^{7}$

\section{Faktor yang mempengaruhi dalam pengelolaan kelas}

Dalam mewujudkan pengelolaan kelas yang baik, terdapat beberapa faktor yang menpengaruhinya, di antaranya: Lingkungan fisik tempat belajar mempunyai pengaruh penting terhadap hasil pembelajaran. Lingkungan fisik yang menguntungkan dan memenuhi syarat minimal mendukung mening- katnya intensitas proses pembelajaran dan mempunyai pengaruh positif terhadap pencapaian tujuan pembelajaran. Lingkungan fisik yang dimaksud meliputi:

1. Ruang tempat berlangsungan proses belajar mengajar

\footnotetext{
Sunhaji, 3:98-99.
} 
Ruangan tempat belajar harus memungkinkan semua siswa bergerak leluasa tidak berdesak-desakan dan saling menganggu antara siswa yang satu denganyanglainnyapadasaatmelakukan aktivitas belajar. Besarnya ruangan kelas tergantung pada jenis kegiatan dan jumlah siswa yang melakukan kegiatan. Jika ruangan tersebut mempergunakan hiasan, pakailah hiasan. hiasan yang mempunyai nilai pendidikan.

2. Pengaturan tempat duduk

Dalam mengatur tempat duduk yang penting adalah memungkinkan terjadinya tatap muka, dengan demikian guru dapat mengontrol tingkah laku siswa. Pengaturan tempat duduk akan mempengaruhi kelancaran proses belajar mengajar.

3. Ventilasi dan pengaturan cahaya suhu, ventilasi dan penerangan (kendati pun guru sulit mengatur karena sudah ada) adalah aset penting untuk terciptanya suasana belajar yang nyaman. Oleh karena itu ventilasi harus cukup menjamin kesehatan siswa.

4. Pengaturan penyimpanan barangbarang Barang-barang hendaknya disimpan pada tempat khusus yang mudah dicapai bila diperlukan dan akan dipergunakan bagi kepentingan belajar. Barang-barang yang karena nilai praktisnya tinggi dan dapat disimpan di ruang kelas seperti buku pelajaran, pedoman kurikulum, kartu pribadi dan sebagainya, hendaknya ditempatkan sedemikian rupa sehingga tidak mengganggu gerak kegiatan siswa. Tentu saja masalah pemeliharaan juga sangat penting dan secara veriodik harus dicek dan recek. Hal lainnya adalah pengamanan barang-barang tersebut, baik dari pencurian maupun barang-barang yang mudah meledak atau terbakar. ${ }^{8}$

Suhaenah Suparno, mengemukakan kriteria yang harus dipenuhi ketika melakukan penataan fasilitas ruang kelas sebagai berikut. ${ }^{9}$

1. Penataan ruangan dianggap baik apabila menunjang efektifitas proses pembelajaran yang salah satu petunjuknya adalah bahwa anak-anak belajar dengan aktif dan guru dapat mengelola kelas dengan baik.

2. Penataan tersebut bersifat fleksibel (luwes) sehingga perubahan dari satu tujuan ke tujuan yang lain dapat dilakukan sedemikian rupa sehingga sesuai dengan sifat kegiatan yang dituntut oleh tujuan yang akan dicapai pada waktu itu.

3. Ketika anak belajar tentang suatu konsep, maka ada fasilitas-fasilitas yang dapat memberikan bantuan untuk memperjelas konsep konsep tersebut yaitu berupa gambar-gambar atau model atau media lain sehingga konsep konsep tersebut tidak bersifat verbalitas. Tempat penyimpanan alat dan media tersebut cukup mudah dicapai sehingga waktu belajar siswa tidak terbuang.

4. Penataan ruang dan fasilitas yang ada di kelas harus mampu membantu siswa meningkatkan motivasi siswa untuk belajar sehingga mereka merasa senang belajar. Indikator ini tentu tidak dengan dengan segera diketahui, tetapi guru yang berpengalaman akan dapat melihat apakah siswa belajar dengan senang atau tidak.

8 Majid Abdul, Perencanaan Pembelajaran: Mengembangkan Standar Kompetensi Guru (Bandung: Remaja Rosdakarya, 2013), 167.

9 Suparno, Dimensi-dimensi Mengajar (Bandung: Sinar Baru, 2001), 84. 


\section{Tujuan Pengelolaan Kelas}

Suwarna mengatakan bahwa pengelolaan kelas merupakan keterampilan guru menciptakan dan memelihara kondisi belajar yang optimal dan mengembalikannya apabila terjadi gangguan dalam proses belajar mengajar. Keterampilan tersebut bertujuan untuk:

1. Mendorong siswa mengembangkan tingkah lakunya sesuai tujuan pembelajaran.

2. Membantu siswa menghentikan tingkah lakunya yang menyimpang dari tujuan pembelajaran.

3. Mengendalikan siswa dan sarana pembelajaran dalam suasana pembelajaran yang menyenangkan, untuk mencapai tujuan pembelajaran.

4. Membina hubungan interpersonal yang baik antara guru dengan siswa dan siswa dengan siswa, sehingga kegiatan pembelajaran menjadi efektif. ${ }^{10}$

Maka dengan demikian, tujuan pelaksanaan pengelolaan kelas adalah sebagai upaya guru untuk mengendalikan tingkah laku siswa di dalam kelas dengan membina hubungan yang baik antara guru dengan siswa ataupun siswa dengan siswa agar dapat menciptakan kondisi kelas yang kondusif saat proses pembelajaran berlangsung.

\section{Prosedur Pengelolaan Kelas Komponen Pengelolaan Kelas}

Prosedur adalah cara mengerjakan suatu pekerjaan menurut tingkattingkatnya. Prosedur pada dasarnya adalah suatu susunan yang teratur dari kegiatan yang berhubungan satu sama lainnya dan prosedur-prosedur yang berkaitan melaksanakan dan memudahkan kegiatan

\footnotetext{
10 S. M. Suwarna, Pengajaran Mikro (Yogyakarta: Tri Wacana, 2005), 82-83.
}

utama dari suatu organisasi. Sedangkan pengertian prosedur menurut Ismail Masya mengatakan bahwa "prosedur adalah suatu rangkaian tugas-tugas yang saling berhubungan yang merupakan urutan-urutan menurut waktu dan tata cara tertentu untuk melaksanakan suatu pekerjaan yang dilaksanakan berulangulang". 11

Dengan demikian prosedur pengelolaan kelas adalah serangkaian langkah kegiatan pengelolaan kelas yang dilakukan agar tercipta kondisi kelas yang optimal serta mempertahankan kondisi optimal tersebut supaya proses pembelajaran dapat berlangsung secara efektif dan efisien.

Guru yang efektif pada umumnya mempunyai berbagai strategi pengelolaan kelas yang baik dan dapat diimplementasikan sesuai situasi dan kondisi. Dalam mengelola kelas guru perlu mengembangkan komunitas belajar yang menghargai semua siswa, sehingga siswa saling menghormati dan termotivasi untuk bekerja bersama-sama.

Guru seyogyanya mampu mengembangkan etika kepedulian antara guru dengan siswa dan juga antar siswa Pengelolaan kelas merupakan tantangan penting yang dihadapi guru. Seorang guru akan dikenal baik oleh siswa, guru lain, sekolah, dan orang tua siswa bila kemampuan mengelola kelasnya juga baik, yaitu: dapat menangani pembelajaran, menciptakan lingkungan belajaryang tertib, dan menangani berbagai permasalahan dan perilaku siswa. Menurut Cholis Sa'adah terdapat beberapa komponen prosedur pengelolaan kelas, yaitu: pengelolaan kelas preventatif, pengelolaan kelas dengan

\footnotetext{
11 Ismail Masya, Manajemen Penelitian Tindakan Kelas (Jakarta: Airlangga, 1994), 74.
} 
perspektif penguatan, dan pengelolaan kelas yang berpusat pada siswa. ${ }^{12}$

\section{Pengelolaan kelas preventative (Antisipatif)}

Pengelolaan kelas preventatif merupakan perspektif bahwa banyak masalah di kelas dapat diselesaikan dengan merencanakan tujuan pembelajaran yang menarik dan relevan, serta pelaksanaan pembelajaran yang efektif. Jadi pengelolaan kelas akan berjalan baik bila guru merencanakan pembelajaran yang melibatkan siswa dan mencapai tujuan yang diharapkan. Pengelolaan kelas dan pembelajaran saling terkait satu sama lain dan merupakan salah satu bagian dari peran kepemimpinan guru secara keseluruhan. ${ }^{13}$ Dengan kata lain, prosedur preventif ini menyangkut segala tindakan guru sebelum tingkah laku yang menyimpang dan mengganggu proses pengajaran muncul.

Pengelolaan kelas merupakan program pembelajaran yang harus direncanakan dan dilaksanakan guru dengan menggunakan berbagai pertimbangan antara lain: kemampuan siswa, sarana pembelajaran, materi pembelajaran, waktu dan tujuan pembelajaran, proses dan pencapaian pembelajaran, maupun evaluasinya. Ketika guru merencanakan pembelajaran, mereka memastikan pengelolaan kelas yang baik, ketika guru merencanakan alokasi waktu untuk berbagai kegiatan belajar atau mempertimbangkan bagaimana ruang kelas seharusnya ditata, saat itu mereka mengambil keputusan penting yang akan mempengaruhi pengelolaan kelasnya.

\footnotetext{
12 "Badan Pengembangan Sumber Daya Manusia Pendidikan dan Penjamin Mutu Pendidikan, Pengelolaan Kelas dan Penerapanya," Yogyakarta: Kemendiknas, 2011, 7-9.

13 "Badan Pengembangan Sumber Daya Manusia Pendidikan dan Penjamin Mutu Pendidikan, Pengelolaan Kelas dan Penerapanya."
}

Semua strategi untuk membangun komunitas belajar yang produktif, seperti membantu kelas agar dapat berkembang sebagai kelompok, memusatkan perhatian pada motivasi siswa, dan memfasilitasi pembicaraan yang jujur juga merupakan komponen-komponen penting dalam pengelolaan kelas. Setiap model atau strategi pembelajaran yang dipilih oleh guru untuk digunakan, maka akan menuntut pada sistem pengelolaan kelas dan mempengaruhi perilaku guru serta siswa. Tugas-tugas pembelajaran yang terkait dengan ceramah membutuhkan perilaku yang berbeda bagi siswa dibanding perilaku yang dibutuhkan untuk tugas keterampilan. Tuntutan perilaku siswa yang bekerja kooperatif dalam kelompokkelompok kecil berbeda dengan tuntutan untuk mengerjakan tugas mandiri. Berbagai pertimbangan sebagaimana yang telah diuraikan tersebut di atas menjadi gambaran usaha guru dalam mencegah berbagai kemungkinan kegagalan ataupun kendala yang terjadi dalam pelaksanaan pembelajaran.

\section{Pengelolaan kelas dengan perspektif penguatan}

Pengelolaan kelas dengan perspektif penguatan berdasarkan pada pendekatan tingkah laku. Misal guru memberikan reward (hadiah) dengan memberi nilai yang baik, pujian, dan hak istimewa untuk menguatkan perilaku yang diinginkan dari siswa. Pendekatan tingkah laku sering menekankan tentang bagaimana mengontrol perilaku individu-individu siswa dari pada mempertimbangkan kelas sebagai kelompok dan situasi belajar secara keseluruhan. ${ }^{14}$

\footnotetext{
14 "Badan Pengembangan Sumber Daya Manusia Pendidikan dan Penjamin Mutu Pendidikan,
} 
Menurut perspektif penguatan, guru dapat mendorong perilaku yang diinginkan melalui pemberian hadiah, hak istimewa, dan pujian. Pujian mudah diberikan oleh guru tapi harus digunakan dengan tepat agar efektif. Hukuman dan sangsi digunakan untuk mengurangi pelanggaran aturan dan prosedur. Pedoman penggunaan sangsi menurut perspektif penguatan, adalah sebagai berikut;

a. Gunakan pengurangan skor untuk tugas atau pekerjaan yang terkait dengan perilaku, misalnya jika siswa tidak mengumpulkan pekerjaan yang tidak dikerjakan sampai selesai.

b. Gunakan denda untuk menangani pengulangan pelanggaran terhadap aturan dan prosedur. Berikan peringatan pertama, dan bila perilaku berlanjut berikan denda. contoh denda: berupa gambar-gambar yang harus dibayarkan karena melanggar aturan atau bentuk lain sesuai kesepakatan kelas.

c. Bila anda memiliki siswa yang sering menerima sangsi, bantulah mereka agar merencanakan untuk menghentikan perilaku buruknya. Contoh: guru dengan kalimat halus menyuruh siswa yang berperilaku buruk untuk membaca aturan kelas yang telah disepakati bersama. ${ }^{15}$

\section{Prosedur Kuratif (Penyembuhan)}

Merupakan tindakan tingkah laku yang menyimpang yang sudah terlanjur terjadi. Tujuan dari prosedur ini agar penyimpangan tersebut tidak berlarutlarut dan guru dapat mengembalikan kondisi kelas yang menguntungkan bagi berlangsungnya proses belajar.

Pengelolaan Kelas dan Penerapanya," 8.

15 "Badan Pengembangan Sumber Daya Manusia Pendidikan dan Penjamin Mutu Pendidikan, Pengelolaan Kelas dan Penerapanya."
Adapun langkah-langkahnya yaitu:

a. Mengidentifikasi masalah, gunanya untuk mengenal dan mengetahui masalah-masalah pengelolaan kelas.

b. Menganalisis masalah, gurumenganalisis penyimpangan siswa dan menyimpulkan latar belakang dan sumber-sumber dari penyimpangan, selanjutnya menentukan alternatif penanggulangannya.

c. Menilai alternatif pemecahaan, guru menilai alternatif pemecahan yang sesuai, kemudian memilih alternatif pemecahan yang dianggap sudah tepat serta melaksanakannya.

d. Mendapatkan balikan, guru melakukan kilas balik agar alternatif pemecahan yang dipilih tadi sesuai target yang sudah direncanakan. Dengan cara guru membentuk pertemuan dengan peserta didiknya untuk perbaikan dan kepentingan siswa dan sekolah, sematamata untuk kepentingan bersama. ${ }^{16}$

Prosedur kelas harus dimonitor dengan baik. Guru juga harus merespons kepada hampir setiap penyimpangan peraturan atau prosedur. Ketika guru mengumumkan bahwa kelas atas siswa individu tidak benar mengikuti prosedur, pendekatan terbaik adalah untuk meminta siwa menetapkan prosedur yang benar dan kemudian mempraktikkannya.

\section{Pengelolaan kelas yang efektif}

Agar pengelolaan kelas bisa berjalan dengan efektif, maka perlu dikembangkan oleh para guru prinsip-prinsip pengelolaan kelas sebagaimana berikut :

\footnotetext{
16 Sodikin dkk, Manajemen Penelitian Tindakan Kelas (Jakarta: Airlangga, 2002), 27.
} 


\section{Menegakkan aturan dan menerapkan prosedur}

Untuk mempersiapkan pengelolaan kelas yang efektif, siswa harus mengetahui aturan kelas dan prosedur. Aturan kelas adalah pernyataan yang menyebutkan apa yang diharapkan untuk dilakukan dan tidak dilakukan oleh siswa.Biasanyaaturandibuat secara tertulis dan dimengerti dengan jelas oleh siswa. Sedangkan prosedur adalah cara untuk menyelesaikan pekerjaan atau kegiatan dan jarang yang dibuat dalam bentuk tertulis. ${ }^{17}$ Prosedur kelas ditetapkan oleh guru untuk menangani tugas-tugas rutin dan menginstruksikan apa yang seharusnya dilakukan siswa. Pengelolaan kelas yang efektif akan terwujud bila konsisten dalam menegakkan aturan dan menerapkan prosedur. Bila tidak, aturan dan prosedur apapun akan hilang dengan cepat.

Aturan dan prosedur perlu diajarkan, dalam mengajarkannya, guru perlu menjaga konsistensi, mencegah perilaku menyimpang dalam pembelajaran, dan mengkonsentrasikan kegiatan kelas selama periode yang tidak stabil, yaitu ketika tata tertib paling sulit dicapai dan dipertahankan. Misalnya pada saat memulai pelajaran, saat masa transisi,dan saat mengakhiri pelajaran.

Guru mencegah perilaku menyimpang dengan melancarkan pembelajaran, yaitu menghindari masalah-masalah yang sering mengganggu kelancaran pelajaran. Masalah-masalah yang sering mengganggu kelancaran pelajaran tersebut antara lain: guru memulai kegiatan pembelajaran dan kemudian membiarkannya menggantung tanpa penyelesaian, guru memecah suatu

\footnotetext{
17 “Badan Pengembangan Sumber Daya Manusia Pendidikan dan Penjamin Mutu Pendidikan, Pengelolaan Kelas dan Penerapanya," 9.
}

kegiatan pembelajaran menjadi unit-unit yang terlalu kecil, guru mengulang-ulang pembelajaran yang sudah dimengerti dengan jelas oleh siswa. Hal demikian itu dapat diantisipasi dengan langkah sebagaimana berikut, umpamanya pada saat memulai pelajaran dapat dilakukan antara lain guru menyambut kedatangan siswa-siswi di pintu kelas dan mengucapkan selamat datang. Guru sudah menulis tujuan pembelajaran hari itu di papan tulis sehingga segera dapat memulai pelajaran begitu masuk ke ruang kelas.

Masa transisi (peralihan) adalah waktu perpindahan selama pelajaran yang dilakukan guru dari satu tipe kegiatan belajar ke tipe kegiatan belajar lain. Misal dari kegiatan diskusi menuju kegiatan presentasi hasil. Untuk memberi tanda bahwa transisi segera terjadi atau untuk membantu guru menjalani transisi dengan lancar antara lain dapat dilakukan dengan memberi isyarat atau sinyal. Contoh isyarat antara lain: guru memberi isyarat dengan mendekati setiap kelompok bahwa waktu diskusi kelompok kecil berakhir 5 menit lagi. Sedangkan contoh sinyal antara lain dengan tepuk tangan, pandangan mata, dan tanda bel, lampu, jari, atau jempol.

Pada waktu mengakhiri pelajaran dapat dilakukan antara lain dengan menyisakan waktu yang cukup untuk menyelesaikan kegiatan penutup. Memberi pekerjaan rumah lebih awal sehingga ketidakjelasan selama pembelajaran dapat diatasi sebelum menit terakhir pelajaran. Menetapkan prosedur rutin untuk mengumpulkan pekerjaan siswa, misal dengan meletakkan kotak di samping pintu dan siswa harus memasukkan pekerjaannya di kotak tersebut. 


\section{Mengembangkan tanggung jawab} siswa

Untuk mempersiapkan pengelolaan kelas yang efektif, guru perlu mengembangkan tanggung jawab kepada siswa. Hal-hal yang dapat dilakukan antara lain sebagaiberikut. Guru mengkomunikasikan dengan jelas tugastugas dan persyaratan untuk menyelesaikan tugas dan guru perlu pula mengetahui kemajuan siswa setelah tugas diberikan. ${ }^{18}$

Sebagai contoh, bila tugas dilakukan di dalam kelas guru dapat berjalan mengitari kelas untuk memeriksa dan memberi bimbingan. Jika tugas-tugas jangka panjang, atau waktu yang lama, sebaiknya dipecah menjadi bagian-bagian yang lebih kecil dan siswa dibimbing membuat laporan kemajuan secara bertahap. Guru memeriksa secara konsisten pekerjaan yang telah diselesaikan oleh siswa dan memberikan umpan balik pada hasil pekerjaan tersebut.

\section{Menangani perilaku yang tidak semestinya dan mengganggu}

Menurut Glasser, bila siswa berperilaku buruk di sekolah, guru sering menunjuk pada keadaan rumah yang tidak menguntungkan sebagai alasannya. Padahal seringkali alasan sebenarnya adalah karena siswa tersebut menganggap sekolah tidak cukup memuaskan dirinya. Guru seharusnya menyadari bahwa siswa tersebut ingin terpenuhi semua kebutuhan dan pengalaman belajarnya di kelas. Bila guru cukup sabar untuk menghadapi ketidakmampuan siswa dalam belajar, maka siswa akan memiliki peluang cukup

\footnotetext{
18 "Badan Pengembangan Sumber Daya Manusia Pendidikan dan Penjamin Mutu Pendidikan, Pengelolaan Kelas dan Penerapanya," 13.
}

banyak untuk mendapatkan pengalaman yang lebih baik. $^{19}$

Untuk menangani perilaku buruk, antara lain guru memiliki keterampilan whit-it (cepat dan akurat) dan overlapping (tumpang tindih). Keterampilan whitit adalah keterampilan guru menangani perilaku yang menyimpang dari siswa dengan cepat dan akurat. ${ }^{20}$ Contoh: bila siswa berperilaku menyimpang, maka guru langsung menegur dan menyuruh siswa membaca aturan kelas yang telah disepakati, agar siswa menyadari perilaku yang dilakukan menyimpang dari aturan kelas.

Keterampilan overlapping adalah keterampilan guru untuk menangani siswa yang berperilaku tidak semestinya secara tidak menyolok, sehingga pelajaran tidak terganggu. $^{21}$ Misal dengan meletakkan tangan guru pada pundak siswa yang sedang berbicara dengan teman sebelahnya padahal bukan waktu berdiskusi, dan sambil terus melanjutkan instruksinya.

Keterampilan whit-it maupun overlapping membutuhkan kemampuan guru untuk membaca situasi kelas dengan cepat dan akurat serta kemampuan untuk melaksanakan pembelajaran serta menangani perilaku siswa yang menyimpang. Apabila guru dapat melaksanakan keterampilan-keterampilan tersebut, maka pengelolaan kelas akan berjalan dengan lancar. Sebagai misal saja apabila siswa menunjukkan perilaku buruk, maka guru mendekati tempat duduk siswa. Bila perilaku buruk tersebut masih terlihat, maka guru perlu melakukan "kontak mata" dengan siswa, dan seterusnya. Guru dapat pula mengkombinasikan penanganan

19 Azhar Imam, Pengelolaan Kelas dari Teori ke Praktek (Yogyakarta: Insyira, 2013), 67.

20 Imam, 67.

21 Imam, 69. 
perilaku buruk siswa sesuai dengan tujuan yang ingin dicapai.

\section{Merespon perilaku siswa yang menyimpang}

Seringkali siswa berperilaku menyimpang atau tidak mengerjakan tugas-tugas yang diberikan guru, misal mengganggu teman. Dengan adanya perilaku menyimpang, maka guru harus merespon tindakan menyimpang tersebut. Contoh respon guru terhadap perilaku menyimpang sebagaimana berikut :

a. Respon kejelasan (clarity). Guru jelas atau spesifik menyebutkan apa yang salah dari perilaku yang menyimpang dari siswa. Contoh: "Hentikan", "Jangan meraut pensilmu jika saya sedang menerangkan pelajaran"

b. Respon ketegasan (firmness). Guru mengkomunikasikan keseriusannya dalam menanggapi perilaku yang menyimpang dari siswa. Contoh: "Saya minta jangan lakukan itu lagi" atau "Saya tidak menoleransi perbuatanmu"

c. Respon kekerasan (roughness). Guru mengkomunikasikan kemarahannya dalam menanggapi perilaku yang menyimpang dari siswa. Contoh: "Seharusnya kau tidak melakukannya lagi" atau "Kalau kau melakukannya lagi, saya akan marah dan menghukummu". 22

Dari rangkaian respon di atas diterapkan guru secara bertahap melihat situasi dan perubahan prilaku yang terjadi pada peserta didik, jika hanya dengan menggunakan respon pertama saja peserta didik dapat berubah lebih baik dan menyadari atas kesalahanya, maka tidak perlu ada tahapan respon selanjutnya.

\footnotetext{
22 Suyono Hariyanto, Belajar dan Pembelajaran: Teori dan Konsep Dasar (Bandung: Remaja Rosda Karya, 2011), 78.
}

Namun bila guru melihat ada indikasi peserta didik tidak ada perubahan, maka guru sesegera mungkin mengambil langkah pada respon berikutnya sampai pada tindakan pemberian sanksi bila terpaksa harus dilakukan.

\section{Hal-hal dalam Menciptakan Kondisi yang Efektif dalam Pengelolaan Kelas}

Dalam upaya untuk menciptakan kondisi yang efektif dalam pengelolaan kelas, maka harus diketahui hal-hal sebagai berikut.

1. Diketahui secara tepat faktorfaktor mana akah yang saja dapat menunjang terciptanya kondisi yang menguntungkan dalam proses belajar mengajar. Di antara faktor-faktor yang dapat menunjang terciptanya kondisi yang menguntungkan tersebut adalah di bawah ini:

a. Menanamkan kebiasaan yang baik di dalam kelas. Salah satu kondisi tertib yang perlu ditanamkan kepada siswa adalah kebiasaan yang baik untuk menunukan jari (mengacungkan tangan) apabila ingin berbicara atau mengajukan pertanyaan. Tindakan seperti ini perlu diawali dengan informasi guru menganai apa yang harus dilakuka yakni bahwa siswa harus mengacungkan tangan sebelum mengutarakan maksud/mengajukan pertanyaan.

b. Menegur secara manusiawi. Teguran seorang guru bagi diri siswa walaupun tampaknya kecil tetapi sebetulnya dirasakan mendalam oleh siswa. Misalnya kata mengapa kamu berdiri dari tempat dudukmu? sambil guru itu mendekatinya dan berkata." Kamu selalu saja berbuat apa saja yang menjengkelkan hati saya 
"disusul dengan ucapan lain "Kamu tidak bisa berbuat sopan, ya. Teguran semacam itu dapat menimbulkan suasan ketegangan dalam kelas, yang akhirnya dapat merendahkan prestasi belajarnya.

c. Dikenal masalah-masalah apa saja yang diperkirakan dan bisa timbul dan dapat merusak iklim belajar mengajar. Hal ini harus diantisipasi dengan tindakan preventif seperti sikap terbuka, demokratis, menguasai bahan pelajaran, komunikatif, dan sebagainya, dan dengan tindakan kuratif yakni mengembalikan kondisi yang optimal jika terjadi baik dengan cara mendisiplinkan ataupun gangguan berbagai pendekatan modifikasi perilaku lainnya.

d. Dikuasainya berbagai pendekatan dalam pengelolaankelas dan diketahui pula kapan dan untuk masalah mana serta pendekatan apa yang digunakan. Baik pendekatan modifikasi perilaku positif, negatif, penghapusan ataupun hukuman, pendekatan iklim sosial emosional, maupun pendekatan proses kelompok. ${ }^{23}$

2. Selain beberapa hal tersebut di atas, ada beberapa prinsip yang harus diperhatikan dalam melaksanakan pengelolaan kelas antara lain:

a. kehangatan dan keantusiasan,

b. penggunaan bahan-bahan yang menantang bagi usaha meningkatkan gairah belajar siswa,

c. perlu dipertimbangkan penggunaan variasi media, gaya mengajar, dan pola interaksi,

\footnotetext{
${ }^{23}$ Sunhaji, Strategi Pembelajaran, Konsep Dasar, Metode, dan Aplikasi dalam Proses Belajar Mengajar, 3:100-101.
}

d. diperlukan keluwesan tingkah laku guru dalam mengubah strategi mengajarnya untuk mencegah gangguan-gangguan yang timbul, dan

e. mendorong siswa untuk mengembangkan disiplin diri sendiri dengan cara memberi contoh dalam perbuatan guru sehari-hari. ${ }^{24}$

Peningkatan mutu pendidikan akan tercapai apabila proses belajar mengajar yang diselenggarakan di kelas benarbenar efektif dan berguna untuk mencapai kemampuan pengetahuan, sikap dan keterampilan yang diharapkan. Karena pada dasarnya proses belajar mengajar merupakan inti dari proses pendidikan secara keseluruhan, di antaranya guru merupakan salah satu faktor yang penting dalam menentukan berhasilnya proses belajar mengajar di dalam kelas.

Berbagai kendala akan senantiasi ditemui dan dirasakan oleh guru dalam rutinitas proses belajar mengajar. Namun demikian seorang guru tidak boleh merasa jemu dan acuh dalam menyelesaikan permasalahan yang ada. Indikator besar yang menjadi penyebab kegagalan dalam pengelolaan kelas adalah karena kurangnya kemampuan guru dalam mempersiapkan segala hal yang berhubungan dengan proses pembelajaran dalam kelas, mulai dari persiapan materi, bahan ajar, media pembelajaran dan yang lain, dan juga kurangnya kemampuan guru dalam mengkondisikan dan mengelola kelas dengan baik.

Kemampuan guru dalam pengelolaan kelas menjadi juru kunci keberhasilan peserta didik untuk mencapai pendidikan yang efektif dan efisien. Untuk itu

\footnotetext{
${ }^{24}$ J. J. Hasibuan, Ibrahim, dan A. J. E. Toenlioe, Proses Belajar Mengajar: Ketrampilan Dasar Pengajaran Makro (Bandung: Remaja Rosda Karya, 1993), 84.
} 
diperlukan langkah-langkah yang konkrit dalam mewujudkan keberhasilan pengelolaan kelas.

Disini penulis mencoba menawarkan beberapa tips yang dapat digunakan untuk mengantisipasi atau mengurangi kegagalan dalam pengelolaan kelas, diantaranya adalah ;

1. Memahami teori pembelajaran.

Teori tentang pembelajaran harus dikuasai namun tidak diterapkan mentah-mentah. Referensi digunakan dapat dimodifikasi sesuai dengan kebutuhan dan kondisi siswa di lapangan. Karakter siswa berbeda di daerah pedesaan atau perkotaan, sekolah unggulan dan non unggulan. Itu artinya, mengelola pembelajaran tidak dapat disamaratakan caranya. Misalnya ketika mengelola pembelajaran di kelas non-unggulan akan berbeda dengan mengajar di kelas unggulan.

2. Menguasai materi pembelajaran

Guru harus menguasai materi pelajaran yang akan diajarkan. Dengan demikian guru akan percaya diri berdiri di depan kelas tanpa banyak melihat buku sumber.Tersendatnya pembelajaran sering disebabkan karena guru kurang menguasai materi pelajaran. Atau guru tidak siap mengajar karena situasi dan keadaan tertentu.

3. Gaya mengajar yang khas

Yang tak kalah penting adalah stil atau gaya mengajar yang ditunjukkan guru ketika menghadapi siswa di dalam kelas. Gaya mengajar meliputi penampilan, gaya dan cara berbahasa, serta sikap guru. Pembelajaran akan mudah dikelola melalui unsur-unsur stil mengajar yang disebutkan. Guru perlu memiliki stil mengajar yang khas.
4. Gunakan metode mengajar yang pas Metode mengajar disesuaikan dengan karakteristik materi pelajaran dan pesertadidik.Metodeceramahdigunakan bila guru yakin akan kemampuan berceramah cukup memadai. Akan tetapi jika tidak memungkinkan, guru dapat menggunakan metode lain yang dianggap dapat memudahkan dalam mengatur siswa dengan baik.

5. Kontrol disiplin belajar

Disiplin belajar dilaksanakan bersifat konsisten dan kontinyu. Ada aturan yang jelas dan spesifik sebelum memulai maupun mengakhiri pembelajaran. Misalnya, pelajaran belum akan dimulai sebelum semua siswa berada dalam. Kalau pelajaran sudah diumulai, siswa yang terlambat tidak boleh masuk kelas. Konsentrasi belajar akan buyar ketika siswa datang terlambat dan diizinkan masuk kelas. Atau diijinkan masuk kelas dengan ketentuan tertentu.

6. Kesiapan siswa

Tidak memulai belajar kalau siswa belum siap adalah langkah efektif untuk mengelola siswa. Siap mental menerima pelajaran, siap peralatan belajar seperi alat tulis, dan lain sebagainya.

Minimal dengan 6 tips di atas menjadi upaya berarti bagi guru dalam mengelola kelas dengan baik. Tentu saja masih banyak tips lain yang dapat dikembangkan dalam mengelola pembelajaran. Namun semuanya tergantung pada daya kreativitas dan inovasi masing-masing guru. Selamat mencoba.

\section{Penutup}

Dari pembahasan di atas dapatlah kiranya disimpulkan sebagaimana berikut : 
1. Pengertian pengelolaan kelas adalah kegiatan yang terencana yang sengaja dilakukan oleh guru dengan tujuan untuk menciptakan dan mempertahankan kondisi yang optimal, membangun iklim sosio-emosional yang positif serta menciptakan suasana hubungan interpersonal yang baik. Sehingga diharapkan proses belajar dan mengajar dapat berjalan secara efektif dan efesien, sehingga tercapai tujuan pembelajaran.

2. Tujuan pengelolaan kelas adalah mendorong, membantu, mengendalikan dan membina peserta didik sehingga sampai pada tujuan akhir dari proses pembelajaran, yaitu tercapainya ketuntasan dalam proses belajar mengajar.

3. Prosedur mengelolaan kelas terbagi menjadi tiga tahapan yaitu, langkah preventive, penguatan dan kuratif.

\section{DAFTAR PUSTAKA}

Abdul, Majid. Perencanaan Pembelajaran: Mengembangkan Standar Kompetensi Guru. Bandung: Remaja Rosdakarya, 2013.

Arikunto, Suharsimi. Pengelolaan Kelas dan Siswa. Jakarta: Bumi Aksara, 2001.

"Badan Pengembangan Sumber Daya Manusia Pendidikan dan Penjamin Mutu Pendidikan, Pengelolaan Kelas dan Penerapanya." Yogyakarta: Kemendiknas, 2011.

dkk, Sodikin. Manajemen Penelitian Tindakan Kelas. Jakarta: Airlangga, 2002.

E, Komar, dan Uus Rusnadi. Pengelolaan Belajar dan Kelas. Jakarta: PT Setia Mulya, 1993.
Hariyanto, Suyono. Belajar dan Pembelajaran: Teori dan Konsep Dasar. Bandung: Remaja Rosda Karya, 2011.

Hasibuan, J. J., Ibrahim, dan A. J. E. Toenlioe. Proses Belajar Mengajar: Ketrampilan Dasar Pengajaran Makro. Bandung: Remaja Rosda Karya, 1993.

Imam, Azhar. Pengelolaan Kelas dari Teori ke Praktek. Yogyakarta: Insyira, 2013.

Kebudayaan, Peraturan Menteri Pendidikan dan. "Nomor 22 Tahun 2016 Tentang Standar Proses Pendidikan Dasar Dan Menengah." Jakarta: Kementerian Pendidikan dan Kebudayaan, 2016.

Masya, Ismail. Manajemen Penelitian Tindakan Kelas. Jakarta: Airlangga, 1994.

Sunhaji. Strategi Pembelajaran, Konsep Dasar, Metode, dan Aplikasidalam Proses Belajar Mengajar. Vol. 3. Yogyakarta: Grafindo Litera Media, 2009.

Suparno. Dimensi-dimensi Mengajar. Bandung: Sinar Baru, 2001.

Suwarna, S. M. Pengajaran Mikro. Yogyakarta: Tri Wacana, 2005.

Wijaya, Cece, dan A. Tabrani Rusyan. Kemampuan Dasar Guru dalam Proses Belajar Mengajar. Bandung: Rosda Karya, 1992. 